\title{
Availability of seed for hill country adapted forage legumes
}

\author{
S. MONK ${ }^{1}$, D.J. MOOT ${ }^{3}$, B. BELGRAVE ${ }^{1}$, M.P. ROLSTON ${ }^{2}$ and J.R. CARADUS ${ }^{1}$ \\ ${ }^{1}$ Grasslanz Technology Limited, Private Bag 11008, Palmerston North 4442, New Zealand \\ ${ }^{2}$ AgResearch, Lincoln Research Centre, Private Bag 4749, Christchurch 8140, New Zealand \\ ${ }^{3}$ Field Research Centre, Faculty of Agriculture \& Life Sciences, PO Box 85084, Lincoln University 7647, New Zealand
}

\begin{abstract}
New Zealand hill and high country are marginal environments for perennial ryegrass and white clover. Other pasture species, particularly legumes, provide more productive and persistent options for the range of soil climate and topography found in these environments. On cultivatable hill country, lucerne (alfalfa) has been successfully introduced to dryland areas with imported seed increasing five-fold to 210 $\mathrm{t}$ per annum over the last decade. This has led to the first release of a New Zealand selected cultivar in 20 years. For subterranean clover reliance on hardseeded Australian cultivars that frequently fail to meet New Zealand biosecurity standards means seed supply is inconsistent. The potential exists to create a niche seed market through selection of locally adapted material grown for seed in New Zealand. Lotus pedunculatus is available commercially but seed often fails to meet certification standards and is predominantly used in forestry. Lotus corniculatus requires agronomic research to overcome some management constraints and the re-establishment of seed supply before it would be a viable option for drier hill country. Seed production for perennial lupins in New Zealand is predominantly for an export ornamental market, with some direct relationships with growers allowing onfarm use. Caucasian clover seed production has ceased in New Zealand and the demand for seed particularly from high country farmers is no longer met. The smallseeded annual balansa clover is being integrated into farm systems and its prolific seeding has enabled some on-farm production of seed for personal use. For it and arrowleaf and Persian clovers, imported cultivars are available and a local market is unlikely to thrive until agronomic and hard seed issues are addressed. Seed supply of forage legumes to satisfy demand for hill country is problematic and will require development of different models including grower co-ops, regional seed retailers, and on-farm production for niche markets.
\end{abstract}

Keywords: alfalfa, Lolium perenne, Lupinus polyphyllus, Medicago sativa, perennial ryegrass, Sitona lepidus, Trifolium ambiguum, Trifolium michelianum, Trifolium repens, Trifolium resupinatum, Trifolium subterraneum, Trifolium tumens, Trifolium vesiculosum, white clover

\section{Key messages:}

- To provide farmers with an opportunity to sow legume species that can increase hill and high country pasture productivity there is currently a high reliance on imported seed, which is, typically, not well adapted to New Zealand conditions

- The potential exists to create a niche seed market through selection of locally adapted forage legume germplasm that can be grown for seed in New Zealand

- Potential models to create a more coherent value chain for the local production of legume seed that is adapted to hill and high country areas are explored and evaluated.

\section{Introduction}

The New Zealand pastoral industry is dominated by the success of perennial ryegrass (Lolium perenne) and white clover (Trifolium repens). These two species are suited to high fertility, summer moist, intensively managed farm systems for production of meat, fibre and milk. There are $30+$ cultivars of perennial ryegrass and $20+$ cultivars of white clover commercially available. Seed production, including exports of 20000 tonnes per annum, has a value of at least $\$ 60$ million (Pyke et al. 2004). Their importance in the New Zealand pastoral scene is reflected in the large amount of commercial and public funding into breeding, novel endophytes, hybridisation and genetic modification of traits over the last 5 decades. Their place in the New Zealand farming landscape has been secured through a value chain of research, commercialisation and adoption where all parties have benefited.

This model has made New Zealand a world leader in the development of new ryegrass and clover genetics and associated understanding of their agronomy and integration into farm systems. This was initially based on publically funded research that moved closer to market as it matured. The expansion of the New Zealand dairy industry over the last 2 decades has reinforced this process with demand for ryegrass cultivars that are productive and persistent under increased grazing pressure. A network of commercially supported National Forage Variety Trials (NFVT) allows new genetics to be compared across a range of environments (Easton et al. 2001). A Forage Value Index now aims to drive more specialised information 


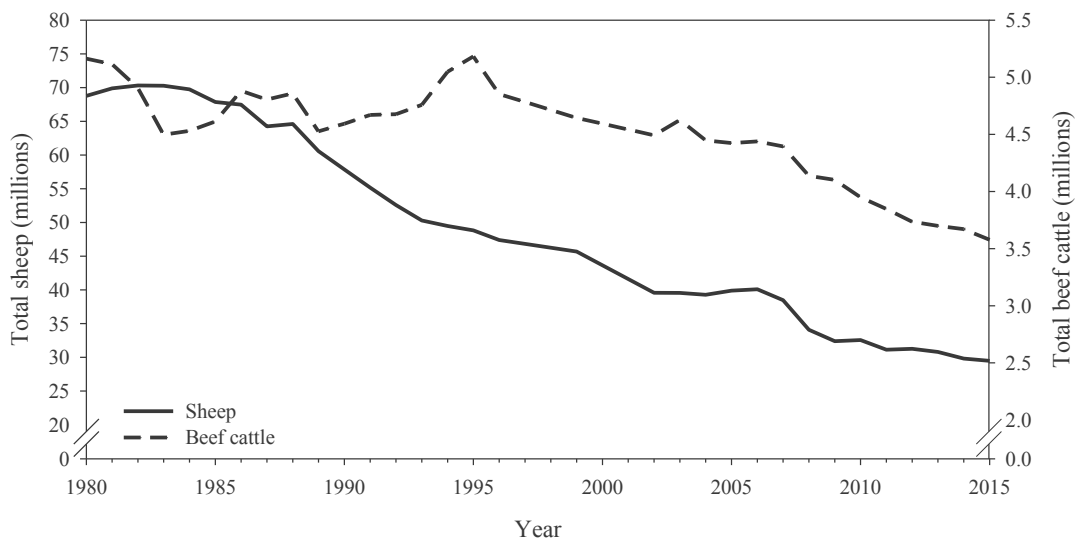

Figure 1 Change in total national sheep and beef cattle numbers (millions) from 1980 to 2015 (Statistics New Zealand 2016). This figure is based on/includes Statistics New Zealand's data which are licensed by Statistics New Zealand for re-use under the Creative Commons Attribution 4.0 International licence.
4) A value chain for commercialisation is required so that there is a sustainable return for the cost of research, and seed production.

These issues have discouraged commercial seed companies investing in this market, and so the consistent seed availability of species other than perennial ryegrass and white clover is low. And without investment to address these issues there will be no market established for alternative plant species. regarding the temporal pattern of ryegrass dry matter production (Chapman et al. 2012).

Arguably, the success and dairy focus for pastoral production and persistence of perennial ryegrass has overshadowed all other pastoral species. There has been limited breeding or agronomic development of other species, including white clover, that may be more appropriate for hill and high country environments.

While the dairy industry has expanded, sheep numbers, and beef to a lesser extent, have declined nationally since the 1980s (Figure 1). Much of the traditional flat "finishing land" is now occupied by dairy farms or used for dairy support. However, about 4.0 million ha of New Zealand is hill country supporting 25 million stock units, that is unlikely to ever be suitable for dairy production as it is steeper, less fertile, topographically and climatically more diverse and challenging, and is more expensive to improve than flatter mostly cultivatable country.

Those remaining in sheep, beef and deer production require higher quality pastures to finish stock on what has been traditional breeding country. For these farmers the choice of pasture species to sow is also dominated by perennial ryegrass and white clover. There are few species options for rolling hill country and especially hard hill and high country. To develop viable options for seed supply, agronomic advice and farm management systems that enhance productivity and minimise the use of $\mathrm{N}$ fertiliser on more extensive farms, there are four issues that need to be addressed:

1) The size of the local market which will determine priorities for investment.

2) Successful on-farm establishment of new species, which can be difficult in these environments, particularly where cultivation is not possible.

3) Seed production to provide reliable seed supply at an acceptable cost.

\section{Legumes for hill and high country}

This paper reviews the potential for other legume species to contribute to hill and high country environments and identifies impediments to their agronomic and commercial success. A current feature of all of these species is a reliance on imported seed which is typically not well adapted to New Zealand conditions (Rumball \& Armstrong 1975; Widdup et al. 2015), or is of old cultivars bred many years ago, and may be uncertified and of inferior quality. Solutions are offered to solve the imbalance of demand and supply for these species, and while this paper focuses on legumes here, that is not to dismiss the important contributions that can be made in hill and high country by grasses such as cocksfoot (Dactylis glomerata).

\section{White clover (Trifolium repens)}

White clover remains the dominant legume species for use in most pastoral applications in New Zealand, including hill and high country regions. Its widespread successful use is due to its phenotypic plasticity and ability to adapt to a wide range of environments and management systems. It does have limitations, including a shallow root system which means it is poorly adapted to drought (Knowles et al. 2003), and a relatively coarse root system (Caradus 1990) which means it is less tolerant of low soil fertility (phosphorus, P) than companion grasses.

Plant breeders have selected for stoloniferous medium to small-leaved types for use in grazed hill country in an attempt to improve vegetative persistence, particularly when grazing is hard and associated with other environmental effects that impact on persistence. In moist hill country cultivars such as 'Tahora' and 'Prestige' have been widely used, but extending their use into dry hill country has not been as successful. Development of a high seed production type to mimic 


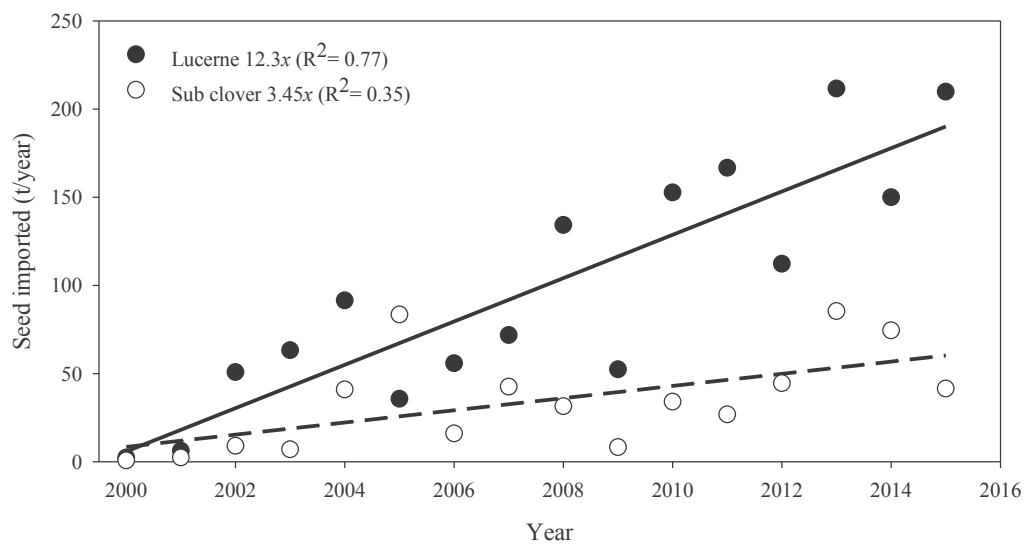

Figure 2 Lucerne and subterranean clover seed imports to New Zealand (data in this figure were supplied by MPI.govt.nz).

annual legumes, that reseed each summer and then reestablish in autumn (Dodd et al. 2001), has not been successfully achieved and/or adopted by farmers.

Plant breeders must continue to seek improvements to white clover adaptation for hill and high country areas with marginal environments of low soil moisture and fertility. Seed production of white clover will continue to be largely focused on cultivars for intensive summer moist environments rather than for more challenging regions where alternative pasture legumes will be required, but current market availability for these is not always apparent.

\section{Lucerne (Medicago sativa)}

New grazing management recommendations (Moot et al. 2003) have offered greater productivity from lucerne (alfalfa) and been advocated by enthusiastic and high profile farmers (e.g. Avery et al. 2008; Anderson et al. 2014). In these cases deeper soils in the valleys and contoured hill country are cultivated or direct-drilled while steeper slopes of poor quality soils and herbage are deliberately left with resident vegetation to provide roughage and other ecosystem services.

Seed importation of lucerne has risen to 210 tonnes in 2015 (Figure 2) suggesting there is 150000 ha of established lucerne in New Zealand based on a $10 \%$ renewal rate sown at a recommended rate of $7-10 \mathrm{~kg} /$ ha. This equates to $\sim 25000$ ha sown per annum. Seed companies have embraced this expansion with a wide range of imported cultivars including European, North American and Australian bred material that provide a range of different winter dormancies, and pest and disease resistance.

The renaissance of lucerne in the sheep and beef industry, as an alternative to ryegrass and clover, has taken a considerable time. It has emerged from two decades of focussed dryland pastures research (Moot 2012) to provide clear management guidelines to support the development of lucerne-based farm systems. The transition from component research to farmer relevant animal liveweight data was supported by the levy funded industry organisation Beef + Lamb New Zealand. The Sustainable Farming Fund (SFF) is a further funding vehicle that supported extension activity (Avery et al. 2008) once the technology was more available.

This pipeline of initially publically funded basic science to investigate solutions, followed by industry supported development and extension, created a sustainable value chain. It offers a template of what could be developed for other species. Ongoing issues remain to be resolved including investigation to quantify any positive or negative environmental impacts of using lucerne in the wider landscape.

As the crop physiology research solved agronomic problems, farmer acceptance generated the demand for seed (Figure 2). This renewed market interest has justified the testing and commercial release of locally selected material (e.g. 'Takahe') to small seed companies operating in a niche market. This is the first New Zealand bred cultivar since the lucerne breeding programme led by DSIR Grasslands was stopped in the early 1990s. Greater demand should further justify the selection of material better adapted to New Zealand conditions. It is expected that this approach will reduce the risk of repeating the 1980s industry collapse through pests and diseases affecting the most commonly used public cultivar 'Wairau'.

\section{Subterranean clover (Trifolium subterraneum)}

Subterranean (sub) clover is the most widely used annual legume for dryland regions in New Zealand. It is the species with the greatest potential to benefit from research work, in a similar manner to lucerne. Sub clover use in New Zealand has been identified by Widdup \& Pennell (2000), Smetham (2003) and latterly Lucas et al. (2015) and MacFarlane et al. (2015), as an appropriate legume for summer dry, drought-prone regions totalling about 3-4 million ha of New Zealand. Sub clover is one of the earliest spring producing legumes and its growth pattern matches the feed demand of lactating ewes and can be used to complement lucerne in a farm systems (Brown et al. 2006).

Despite this, and the demonstrable success of its use on farm (Costello \& Costello 2003; Grigg et al. 2008), the sowing of sub clover in New Zealand farm systems has been variable, and on average, at a much lower 
level than lucerne, given its similar $6-10 \mathrm{~kg} / \mathrm{ha}$ sowing rate (Figure 2). There are several problems to be solved before a larger sustainable value chain can be created in New Zealand requiring a co-ordinated approach.

New Zealand farmers rely exclusively on seed of imported Australian cultivars. Australian seed supply has been underpinned by plant breeding capability in West and South Australia, germplasm banks for sub clovers, and appropriate seed production capability in terms of expertise, equipment, and climate. However, the seed production methods require excavation of seed from below ground and hence many shipments of seed to New Zealand are rejected due to soil contamination. The outcome is sub clover cultivars vary widely in availability between seasons, and importations may be based on seed availability, rather than cultivar choice. This constrains commercial acceptance of the species by seed companies and farmers, and the value chain from seed producer to farmer is fragile. This is one reason for the variable seed importation levels shown in Figure 2.

If new cultivars were developed, a local seed production system would reduce the risk of the biosecurity failure associated with imported seed. However, the production of sub clover seed is an invasive process that raises environmental concerns when buried seed is excavated, and there are no specialist seed harvesters in New Zealand. Whether sub clover seed can be commercially produced in New Zealand, given these difficulties, remains a challenge.

In addition, many of the cultivars imported have an extremely high hardseed level and as a result have not been evaluated for their performance in New Zealand pasture systems (Lucas et al. 2015; MacFarlane et al. 2015) restricting the potential of this species.

There are two local selections available from work undertaken in North Island hill country in the 1980s (Dodd et al. 1995a, b) but no work has taken place since then. A factor in this is that the market size of the various sub clover subspecies required for the different New Zealand environments is small. This makes it difficult to justify investment into a commercial breeding programme for market development. For New Zealand adapted sub clover, the opportunity remains to revisit sites where it has persisted in New Zealand conditions. A key problem to resolve relates to the genetic and environmental interactions around the hardseed levels and, therefore, its ability to regenerate.

Therefore, development of a viable sub clover value chain needs to consider:

1) that locally adapted and/or imported cultivars must

be evaluated in New Zealand conditions, in relation to their ability to improve animal performance (and farm profitability)

2) a reliable seed production system, possibly with local production but with refined seed harvesting techniques

3) solutions for agronomic issues around the introduction of seed into uncultivatable areas, and the successful reseeding of sub clover

4) extension of a comprehensive sub clover management package to maintain it in pasture swards. It seems most likely success will require co-investment initially largely by public funding and when near commercial with private partners.

\section{Caucasian clover (Trifolium ambiguum)}

Little Caucasian clover is currently sown in New Zealand with seed supply an on-going issue. The attributes of Caucasian clover include its perennial and rhizomatous growth habit which have enabled it to survive and thrive, particularly in high country soils of low $\mathrm{pH}$ and high aluminium levels, when other legume species such as white clover and lucerne have failed. However, its slow and often unsuccessful establishment in pastures, and its unreliable seed production and seed availability have limited its use.

Caucasian clover is slow to establish, due to early partitioning below ground and a high thermal time requirement for secondary leaf production (Black et al. 2006). It has been established successfully in lowland pastures when there is little competition from resident or introduced species (Hurst et al. 2000). Lowther et al. (1998) reported it took 6 years to contribute to a high country sward but it has been found to be thriving for up to 30 years in some high country locations (Scott 2014). In the Tekapo high country it became the dominant species under high fertiliser input, but remained a minor species at lower fertiliser input (Scott 1998). In high country pasture environments at eight locations where natural seeding was encouraged the seed set ranged from 23 to $65 \%$ with a high proportion of hard seed, but no assessment of seed yield (Pryor et al. 1996). The authors noted that rhizobia distribution would limit natural spread from seed; Elliot et al. (1998) discussed rhizobia issues for Caucasian clover. Recent work suggests the rhizobia delivery question remains unresolved even at establishment (Black et al. 2014).

Widdup et al. (1996) evaluated the genetic variation in seed yield of 34 accessions of Caucasian clover, including 2x (diploid), 4x (tetraploid) and 6x (hexaploid) material and found that seed yield of $6 \mathrm{x}$ was higher $(1330 \mathrm{~kg} / \mathrm{ha})$ than $4 \mathrm{x}(685 \mathrm{~kg} / \mathrm{ha})$ and $2 \mathrm{x}$ $(1000 \mathrm{~kg} / \mathrm{ha})$. There was also a 5 -fold difference in seed yield between the lowest and highest yielding hexaploid lines. Guy (1996) noted that while row spacing and time of sowing is critical the commercial reality for seed production was about 400 to $500 \mathrm{~kg} / \mathrm{ha}$. Others have also noted that seed production is often low (Hill 1996; Thomas et al. 1998) 
From a commercial perspective Caucasian clover has disappeared as an option for the New Zealand pastoral sector and the momentum to overcome the agronomic issues has been lost. Currently, the value chain, predominantly from high country farmers, is met periodically by availability of imported 'Endura' seed (Stewart et al. 2014). The development of a higher value market chain needs to include:

1) The seed production issue to be solved

2) A consistent rhizobia delivery system to guarantee establishment in harsh environments

3) Methods need to be developed for reliable establishment

4) Locally adapted and/or imported cultivars need to be evaluated in New Zealand conditions, in relation to their ability to improve animal performance (and farm profitability).

The commercial entities that tried to develop a Caucasian clover seed market have ceased its development so it is unlikely this species will be available for New Zealand pastoral farmers without public funding support or grower to grower seed supply.

\section{Perennial lupin (Lupinus polyphyllus)}

Perennial lupin is a legume adapted to acid soils with aluminium levels that are greater than lucerne can tolerate $(>3.0 \mathrm{mg} / \mathrm{kg}$; Moot \& Pollock 2014). The role, potential and management of perennial lupin, including Russell lupin, in New Zealand high country has been well described by Scott (2014). Spread through natural reseeding may be limited by hardseededness but, in contrast to Caucasian clover, there appears to be no issues with nodulation (Ryan-Salter et al. 2014).

Commercial seed crops are grown in Canterbury with seed yields ranging from 100 to $250 \mathrm{~kg} / \mathrm{ha}$ with seed shattering on hot, sunny days being the main cause of year-to-year variation in seed yield (C. Lill pers. comm.). Seed production knowledge was reviewed by Scott et al. (1996) who recommend that lupin crops should be cut when about $25 \%$ of the pods are brown and starting to shatter and then left to dry in the windrow for 2-4 days. They also suggested cutting in the early morning to reduce pod shatter. Direct-heading is also an option using diquat as a desiccant applied when the first pods begin to shatter. While hand-harvested plots have produced seed yields of $1000 \mathrm{~kg} / \mathrm{ha}$ over a 10 days, mechanical harvesting is expected to yield $500 \mathrm{~kg} \mathrm{seed} /$ ha (Scott et al. 1996).

Currently, the species is mainly grown for export to North America for an ornamental market with farmers directly sourcing seed from the grower. The weak point in the value chain is that the niche domestic market is too small to justify extensive public investment. Demand from international growers who experience aluminium levels toxic to lucerne may be necessary before sufficient demand is generated. A targeted programme could select material to create a more palatable perennial legume suitable for grazing in high aluminium soils that dominate many regions worldwide but the limited size and current controversy around sowing it in the high country (Wardle 2016) will restrict its uptake.

\section{Lotus species}

The Lotus genus includes a number of species that are adapted to environmental limitations found in New Zealand hill country as well as having a high feeding value and being bloat safe, through containing condensed tannins (Waghorn et al. 1998). Two species have been developed in New Zealand, with limited commercial success.

Lotus uliginosus syn. pedunculatus a perennial species with a rhizomatous growth habit was identified decades ago as well adapted to low fertility grazed pastures found in moist New Zealand hill country. Cultivars have been developed, notably 'Grasslands Maku', 'Grasslands Sunrise', 'Trojan' and 'Maku II', but availability of commercially produced seed is restricting use. Of these 'Trojan' currently does have commercial seed production, however, most of this is used in the forestry sector rather than for pastoral farming. Seed price and crops failing certification specifications has meant that this potentially useful legume has had extremely limited seed availability. Off-shore seed production is a possible solution and this is currently being explored.

For drier hill country regions, Lotus corniculatus is a perennial, short lived species that has been considered a 'poorer land grazing lucerne' (Scott \& Charlton 1982). Also known as birdsfoot trefoil it is a legume forage with a high feed quality and contains condensed tannin levels that have been noted to have positive anthelmintic effects on animals (reduced daggy sheep/ reduced fly strike, reduced bloat, improved animal production) (Waghorn et al. 1998; Woodward et al. 1999). While New Zealand adapted cultivars, such as 'Grasslands Goldie', have been bred and released, seed production and availability has been a problem (Table 1 ), and 'Goldie' is no longer available.

The challenge for both of these lotus species is that they establish slowly, do not tolerate overgrazing, and if grown with vigorous grass companion species are outcompeted. These limitations are manageable and it is the lack of commercially available seed (Table 1), their reputation as high risk seed crops, and their associated high seed price, which has limited their uptake by pastoral farmers. This means the demand side of the value chain is variable and that leads to inconsistent seed supply.

The value chain would be enhanced, and greater use 
encouraged by pastoral farmers in the more marginal hill country environments through:

1) Proving proof of value for this legume in animal performance

2) Reliable seed supply and production

3) An agronomic management package that allows farmers to obtain the best outcomes from using these species.

A seed grower co-op or grower to grower supply may be required to advance the value chain.

\section{Balansa clover (Trifolium michelianum)}

This aerially seeded annual clover has been used predominantly as a specialist winter annual forage crop with 30 tonne of seed imported in the last 5 years (Table 1).

Balansa was the highest yielding of the top flowering annual clovers in lowland Canterbury (Nori et al. 2015a). It flowers profusely in spring with seed yield potential of 1.5 tonne/ha. It is hardseeded and can regenerate over 3-4 years following seed set (Monks et al. 2008). It has been used as a companion in pasture mixes with a number of species, including plantain in North and South Island pastures but to date has failed to become a significant species in the pastoral sector.

Balansa clover has been established from oversowing in environments of low rainfall but its contribution in the permanent sward to date has been limited. It is considered to be suitable for use in seed mixes with sub clover and well suited to dryland situations. Hard grazing in summer is required to allow regeneration and growth of new seedlings (Monks et al. 2008). Balansa clover has been grown successfully on-farm for forage production in an oversowing situation at Omarama Station in the McKenzie district (R. Subtil pers. comm.). Its prolific aerial seeding allows it to be harvested in a similar manner to red and white clover seed crops without the requirement for specialist machinery. It has a high hardseed level so seed may need to be dressed and scarified before aerially oversowing if it is to make up a large proportion of sown pasture mixes. The slow rate of leaf appearance means that it is often difficult to see in a pasture mix in autumn until increasing daylengths in spring lead to rapid extension of its hollow palatable stem (Nori et al. 2014).

In New Zealand, balansa clover has been shown to persist through natural reseeding under grazing for 3-4 years before it requires resowing (Monks et al. 2008), but it is currently a niche species with little current use in summer dry hill country areas (MacFarlane et al. 2015). The value proposition for balansa clover requires further investigation of hardseededness and the ability to successfully integrate it into a wider range of hill country farm systems by modifying the resident vegetation. It is less likely to become a major component of hill country pastures in areas where summer and autumn rainfall promote grass competition when it is regenerating from seed (Nori et al. 2015b).

Table 1 Quantity of seed $(\mathrm{kg})$ imported annually for minor pasture legume species (data supplied by MPI.govt.nz). There is no New Zealand commercial seed production of these species.

\begin{tabular}{ccccccc}
\hline Year & L. pedunculatus & L. corniculatus & Balansa clover & Arrowleaf clover & Gland clover & Talish clover \\
\hline 2000 & 0 & 400 & 0 & 0 & 0 & 0 \\
2001 & 0 & 0 & 0 & 0 & 0 & 0 \\
2002 & 0 & 66 & 0 & 0 & 0 & 0 \\
2003 & 0 & 1200 & 0 & 0 & 0 & 0 \\
2004 & 0 & 2 & 0 & 0 & 0 & 0 \\
2005 & 0 & $<1$ & 0 & 0 & 0 & 0 \\
2006 & $<1$ & 2 & 0 & 0 & 0 & 0 \\
2007 & 0 & 15225 & 0 & 2000 & 0 & 0 \\
2008 & 0 & $<1$ & 0 & 13752 & NR & 0 \\
2009 & 0 & 0 & 0 & NR & 1000 & 0 \\
2010 & $<1$ & $<1$ & 6 & 6 & 0 & $<1$ \\
2011 & 0 & 63350 & 5005 & 0 & 0 & 0 \\
2012 & 0 & 5001 & 3100 & 5080 & 15 & 0 \\
2013 & 0 & $<1$ & 6775 & 2100 & 0 & $<1$ \\
2014 & 50 & 5 & 17350 & 2000 & 0 & 0 \\
2015 & 0 & $<1$ & 1002 & 1000 & 0 & 0 \\
\hline
\end{tabular}


Seed production is comparatively easy commercially and for on-farm use so the main focus for success is integration into a farm system and potentially further on-farm seed production for personal use.

\section{Gland clover (Trifolium glanduliferum)}

This is an early-flowing annual legume adapted to dry north-facing slopes of hill country, especially in environments where other sown legumes are not adapted. Gland clover has a short growing season of 6 months which does limit its use. It produces excellent winter growth, but flowering in September spells the end of its growth season. It has an extremely hard seed coat and requires hot, dry summers to ensure seed coat cracks so it can regenerate (Nori et al. 2015b). It is small seeded and requires close contact to soil surface at time of sowing, and can to be sensitive to competition from existing vegetation, requiring Group C rhizobia (Nangul et al. 2013; Nori et al. 2014). Seed is imported (Table 1) from Australia and 'Prima' is the main cultivar in the market place (Stewart et al. 2014). For the small size of the potential market, continued reliance on Australianbred and produced seed is expected.

\section{Arrowleaf clover (Trifolium vesiculosum).}

Arrowleaf clover is a high yielding, late flowering annual legume (Nori et al. 2015a) so seed set often may not occur in low rainfall areas with low water holding capacity.

It has a deep tap root and is able to grow in summer dry environments providing quality forage for livestock, especially weaned lambs, over the summer (Stewart et al. 2014). With the very late seed set, high levels of hardseededness are an issue, so seeds may not necessarily germinate the following autumn. Like gland clover, it requires Group C inoculant and nodule occupancy is highly reliant on the inoculant (Nangul et al. 2013). The two main cultivars in the New Zealand market are 'Arrotas' and 'Cefalu' imported from Australia (Table 1). The specialist nature of this species suggests it is likely to remain of limited usage in New Zealand. Therefore, reliance on Australian seed production will likely remain with regional seed companies most likely to provide to a niche market, or farmers will produce seed for personal use.

\section{Persian clover (Trifolium resupinatum)}

Persian clover is an annual forage legume, with its main attribute being high quality spring forage (Nori et al. 2015a). While it flowers and seeds heavily it does not regenerate from seed the following autumn in New Zealand. Consequently, Persian clover tends to be grazed or taken for hay before seeding. It is primarily seen as a winter/spring crop, and is tolerant of waterlogging in winter. Currently two Australian cultivars are marketed ('Lightning' and 'Mihi').

Hardseeded cultivars such as 'Lightening' may have similar issues as arrowleaf clover for use on farm but the soft seeded 'Mihi' has been reported to germinate while still in the calyx (Nori et al. 2015b) which means it may be lost due to a false strike (MacFarlane et al. 2015). Again it is most likely to be serviced by a regionallybased seed company supplying a niche market.

\section{Discussion of options to improve the demand/ supply imbalance}

The existing forage seed industry is working well to service dairy farmers, but little research and development exists for hill and high country due to a real or perceived small market need resulting in little or no investment; but conversely with no investment there will be no market developed. So there is an urgent need for a new model to break this impasse. Decision makers must be persuaded that there is cosiderable benefit for New Zealand in having better animal performance and productivity from hill country through greater legume contribution in pastures. Funding for this in the first instance must come from government and industry good, as the private sector commercial plant breeding organisations will not accept all of the risk for funding research and development for this market. It is a clear case of market failure. So what are the options to retrieve this situation?

The demonstrated increase in lucerne seed sales driven by the development of improved grazing management options suggests that a similar level of success may be possible for other legumes adapted to hill and high country environments. The challenge is to identify the agronomic, seed production and farm management components of the value chain that require solutions. A combination of publically and commercially funded research can then be targeted to ensure their successful incorporation into grazing systems, but these have not been the focus of field-based research for the last 30 years.

The potential models to create a more coherent value chain for legume species adapted to hill and high country areas are listed in Table 2. There are several options for seed supply that do not conform to the main proprietary model used in New Zealand. The facilitation of these new models may require initial public support and ongoing agronomic research to advance seed supply and farmer demand components of the value chain. As demonstrated for lucerne, it may take a decade of basic research and ongoing development and extension to move these species to commercial acceptance. Regional suppliers and grower to farmer supply contracts are more likely to be successful in the short term. Regardless of the model used it will have a requirement for high grade seed maintenance, which has substantial costs associated with it. 


\section{Proprietary seed company model}

This is the main method by which forage cultivars are currently commercialised in New Zealand. This model features reliable high quality seed being available to the trade and farmers. There is an on-going genetic improvement programme through plant breeding and product development and extensive product information on-line and directly available from seed companies and retailer representatives. Royalties generated from sales and paid to the breeder contribute to costs of cultivar maintenance. The focus of this model is on the major forage species (ryegrasses, white clover, red clover, herbs, and tall fescue). These species are generally marketed with protection from plant variety rights (PVR).

This model works well where there is an established, reliable on-going market. The level of investment by commercial breeders is proportional to the size of market such that for a large/high value species like perennial ryegrass for dairy farming there is significant investment. However, for forage legumes in the hill and high country with a small and unreliable market this model does not work. It could be the right model when a hill/high country legume market is established as has been the case for lucerne. For most of the smaller volume niche species that have been shown to have agronomic merit in hill and dryland environments this commercialisation model continues to fail. With respect to commercialisation of forages through the proprietary model all risk is held by the plant breeder and the proprietary seed company, with little risk held by seed producers or end-users in terms of seed supply and the provision of supporting technical information. Until the risk is shared the proprietary model will not be suitable for the seed production of forage legumes specifically for hill/high country pastures.

\section{Grower co-op model (including sole grower)}

This proposed model would be based around a core of growers to produce seed of a minor species and supply to a collective pool, which would then be marketed by a seed company. This model has been successfully used for cocksfoot where the Cocksfoot Growers Association has produced cocksfoot seed of a range of cultivars for marketing companies. Under this model there could be reliable seed availability to the market of minor species, and a royalty collected that could assist with high grade seed costs.

There is likely to be limited technology transfer of seed production or on-going research and development outside of publically funded programmes, and will be reliant on easy availability of suitable germplasm. Under this model most of the financial risk sits with the seed producer as seed is in pools, and reliant on the uptake of seed from the pool from the marketer based on market demand. This is likely to be a more price sensitive market than those species marketed through the proprietary model. Lotus spp., balansa, gland, arrowleaf, and Persian clovers could be further commercialised through this model if there was a move away from reliance on Australian exporters. As with most options an increased demand is required to drive this model. For that to happen hill and high country farmers need to believe there is a value in sowing them, and that they can capture this value in their farm system.

\section{Regional retailer model}

The diversity of topography and soils in New Zealand creates smaller regions with niche requirements such as high aluminium. Servicing these smaller markets may require regional retailers to operate in a similar manner to the grower co-op model. This would be based around a regional retailer where a minor species has adaptation and potential use. This market has informally developed in Marlborough/ North Canterbury and North Otago with retailers directly importing species for dryland regions where ryegrass/white cover fails. In this model the company has the licence and is responsible for production and marketing. Often with these strong regional companies there is technical support and advice available for both the seed producer and end user. Depending on the size of the market there is unlikely to be on-going plant

Table 2 Potential solutions to the demand supply imbalance for species of use in hill country. $\mathrm{Y}=\mathrm{Yes}, \mathrm{N}=\mathrm{No}$.

\begin{tabular}{lcccc}
\hline Commercialisation model & $\begin{array}{c}\text { Proprietary } \\
\text { Seed company }\end{array}$ & $\begin{array}{c}\text { Seed Grower } \\
\text { Co-op }\end{array}$ & $\begin{array}{c}\text { Regional } \\
\text { Retailer }\end{array}$ & $\begin{array}{c}\text { Production for } \\
\text { growers own use }\end{array}$ \\
\hline On-going R\&D and breeding & $\mathrm{Y}$ & $\mathrm{N}$ & $\mathrm{N}$ \\
High grade seed maintenance & $\mathrm{Y}$ & $\mathrm{Y}$ & $\mathrm{Y}$ & $\mathrm{Y}$ \\
Certified seed available & $\mathrm{Y}$ & $\mathrm{N}$ & $\mathrm{N}$ \\
Availability of technology & $\mathrm{Y}$ & Likely to be low & Likely to be low & $\mathrm{N}$ \\
Adoption and end user uptake & $\mathrm{Y}$ & Grower & Company & Low \\
Seed production risk & Breeder \& Company & $\mathrm{Y}$ & Y/N & $\mathrm{N}$ \\
Ability to protect IP & $\mathrm{Y}$ & &
\end{tabular}


breeding or research and development in New Zealand so imported technology will be required. It is also unclear if a royalty based system would operate. The cost associated with producing high grade seed means the breeder/owner will need to bear the costs or pass them on to the consumer. If there is able to be a royalty system some of the cost of high grade seed supply could be covered. However, there is unlikely to be any PVR and the financial risk of importing and stocking seed sits with the regional company.

\section{On-farm production for own use model}

This model would be for species that have agronomic application for a smaller niche area but due to market size and/or seed production limitation it is not financially viable for commercial suppliers. Caucasian clover and perennial lupins could operate under this model. Seed would be made available to farmers for their own production and use. They would require an agreement with the breeder/maintainer of the cultivar but this model will only work if the seed producer and end user do not sell to a third party. The farmer would pay the breeder/ maintainer for the high grade seed which could be up to $\$ 1000 / \mathrm{kg}$ of seed. It is most likely that the producer only purchases once, and then produces, maintains and uses the seed as they see fit. There would be no on-going breeding or technical support and seed of the cultivar would not be commercially available. End users could produce and use the seed for their own use. All the risk of seed production and associated agronomic challenges would sit with the grower/end-user.

\section{New model for the future}

This Symposium is looking to set future directions for hill country farming that add value to both the sheep and beef industry and as a result, New Zealand. One of these would be to identify strategies and practical options to increase legume content of hill and high country pastures. This will require the use of new forage legumes which cannot rely solely on existing seed production and supply chains.

One new initiative might be to bring the key interested parties together in a co-operative approach, which would pool ideas, and also resources, to agree on key objectives and help create the momentum for the change that is needed. The major initial requirement, however, is public and /or industry good funding to address market failure, as there is currently no reliable value chain established for most of the forage legumes discussed.

Research organisations such as AgResearch, are a likely provider of the main part of the research for such a project, and Universities would also provide valuable capability and knowledge. Industry groups, such as Beef and Lamb NZ, would be necessary to represent farmers and provide at least some financial contribution from farmer levies. Seed companies should be involved, as likely producers and providers of seed and management advice around this. Leading farmers would be useful in both providing practical advice, farm land for research, and leadership in profiling the benefits to other farmers. In the long term, the current Proprietary Seed Company model could work, once the value chain is established, as it has been for lucerne. Perhaps the most likely candidate for such an approach is subterranean clover.

\section{ACKNOWLEDGEMENTS}

D.J. Moot acknowledges financial support from Beef + Lamb New Zealand, MAF Sustainable Farming Fund Projects 10-069 and 408090 "Spring into Sub". Perhaps the most likely candidate for such an approach is subterranean clover.

\section{REFERENCES}

Anderson, D.; Anderson, L.; Moot, D.J.; Ogle, G.I. 2014. Integrating lucerne (Medicago sativa L.) into a high country merino system. Proceedings of the New Zealand Grassland Association 76: 29-34.

Avery, D.; Avery, F.; Ogle, G.I.; Wills, B.J.; Moot, D.J. 2008. Adapting farm systems to a drier future. Proceedings of the New Zealand Grassland Association 70: 13-18.

Black, A.D.; Moot, D.J.; Lucas, R.J. 2006. Development and growth characteristics of Caucasian and white clover seedlings, compared with perennial ryegrass. Grass and Forage Science 61: 442-453.

Black, A.D.; Harvey, A.J.; Moir, J.L.; Moot, D.J. 2014. Caucasian clover responses to fertiliser, lime and rhizobia inoculation at Lake Heron Station, Canterbury. Proceedings of the New Zealand Grassland Association 76: 105-109.

Brown, H.E.; Moot, D.J.; Lucas, R.J.; Smith, M. 2006. Sub clover, cocksfoot and lucerne combine to improve dryland stock production. Proceedings of the New Zealand Grassland Association 68: 109-115.

Caradus, J.R. 1990. The structure and function of white clover root systems. Advances in Agronomy 43: 1-46.

Chapman, D.F.; Bryant, J.R.; McMillan, W.H.; Khaembah, E.N. 2012. Economic values for evaluating pasture plant traits. Proceedings of the New Zealand Grassland Association 74: 209-216.

Costello, T.; Costello, A. 2003. Subterranean clover in North Canterbury sheep pastures. Legumes for dryland pastures. Grassland Research and Practice Series 11: 189-192.

Dodd, M.B.; Sheath, G.W.; Richardson, S. 1995a. Development of subterranean clover (Trifolium subterraneum L.) genotypes for New Zealand pastures. 1. Whatawhata persistence evaluation. New Zealand Journal of Agricultural Research 38: 33-47. 
Dodd, M.B.; Sheath, G.W.; Richardson, S. 1995b. Development of subterranean clover (Trifolium subterraneum L.) genotypes for New Zealand pastures 2. Wairakei persistence evaluation. New Zealand Journal of Agricultural Research 38: 49-56.

Dodd, M.B.; Sheath, G.W.; Wedderburn, M.E.; Tarbotton, I.S. 2001. Long-term performance of white clover cultivars oversown into summer-dry hill country. Proceedings of the New Zealand Grassland Association 63: 85-89.

Easton, H.S.; Baird, D.B.; Cameron, N.E.; Kerr, G.A.; Norris, M.; Stewart, A.V. 2001. Perennial ryegrass cultivars: herbage yield in multi-site plot trials. Proceedings of the New Zealand Grassland Association 63: 183-188.

Elliot, D.E.; McIntyre, H.J.; Challis, B.C.; Pryor, H.N.; Lowther, W.L.; Ronson, C.W. 1998. Rhizobium issues affecting the contribution of Caucasian clover to New Zealand pastoral agriculture. Proceedings of the New Zealand Grassland Association 60: 207-211.

Grigg, D.W.; Grigg, J.M.; Lucas, R.J. 2008. Maximising subterranean clover in Marlborough's hill country is key to weaning $80 \%$ of sale lambs prime. Proceedings of the New Zealand Grassland Association 70: 25-29.

Guy, B.R. 1996. Genetic variation for seed yield in Caucasian clover. Proceedings of the New Zealand Grassland Association 58: 195-197.

Hill, M.J. 1996. Caucasian clover. pp. 117-122. In: Practical herbage seedcrop management. Ed. Rowarth, J. Lincoln University Press, Lincoln University.

Hurst, R.G.M.; Black, A.D.; Lucas, R.J.; Moot, D.J. 2000. Sowing strategies for slow-establishing pasture species on a North Otago Dairy farm. Proceedings of the New Zealand Grassland Association 62: 129135.

Knowles, I.M.; Fraser, T.J.; Daly, M.J. 2003. White clover: loss in drought and subsequent recovery. Legumes for dryland pastures. Grassland Research and Practice Series 11: 37-41.

Lowther, W.L.; Pryor, H.N.; Trainor, K.D. 1998. Strategies to maximise establishment and production of oversown caucasian clover. Proceedings of the New Zealand Grassland Association 60: 111-114.

Lucas, R.J.; Mills, A.; Wright, S.; Black, A.D.; Moot, D.J. 2015. Selection of sub clover cultivars for New Zealand dryland pastures. Journal of New Zealand Grasslands 77: 203-210.

MacFarlane, M.J.; Crofoot, E.W.; Muir, P.D. 2015. Effects of closing date on seeding and hardseededness of balansa, gland, Persian and arrowleaf clovers on East Coast dryland. Journal of New Zealand Grasslands 77: 219-225.
Monks, D.P.; Moot, D.J.; Smith, M.C.; Lucas, R.J. 2008. Grazing management for regeneration of balansa clover in a cocksfoot pasture. Proceedings of the New Zealand Grassland Association 70: 233-238.

Moot, D.J.; Brown, H.E.; Teixeira, E.I.; Pollock, K.M. 2003. Crop growth and development affect seasonal priorities for lucerne management. Legumes for dryland pastures. Grassland Research and Practice Series 11: 201-208.

Moot, D.J. 2012. An overview of dryland legume research in New Zealand. Crop and Pasture Science 63: 726-733.

Moot, D.J.; Pollock, K.M. 2014. Perennial lupin establishment and yield when sown at five different rates at Glenmore Station, Lake Tekapo. Proceedings of the New Zealand Grassland Association 76: 5359 .

Nangul, A.; Moot, D.J.; Brown, D.; Ridgway, H.J. 2013. Nodule occupancy by Rhizobium legumininosarum strain WSM1325 following inoculation of four annual Trifolium species in Canterbury, New Zealand. New Zealand Journal of Agricultural Research 56: 215223.

Nori, H.; Moot, D.J.; Monks, D.P.; Black, A.D.; Lucas, R.J. 2014. Reproductive development of four top flowering annual clovers. Crop and Pasture Science 65: 388-399.

Nori, H.; Moot, D.J.; Black, A.D. 2015a. Dry matter and radiation use efficiency of four autumn sown top flowering annual clovers. Journal of New Zealand Grasslands 77: 185-193.

Nori, H.; Monks, D.P.; Moot, D.J. 2015b. Seed development of arrowleaf, balansa, gland and Persian clovers. Journal of New Zealand Grasslands 77: 195-202.

Pryor, H.N.; Lowther, W.L.; Trainor, K.D. 1996. Natural reseeding of Caucasian clover (Trifolium ambiguum) in tussock grasslands. Proceedings of the New Zealand Grassland Association 58: 171-175.

Pyke, N.B.; Rolston, M.P.; Woodfield, D.R. 2004. National and export trends in herbage seed production. Proceedings of the New Zealand Grassland Association 66: 95-102.

Rumball, W.; Armstrong, C.S. 1975. The performance of overseas ryegrass cultivars in New Zealand. Proceedings of the New Zealand Grassland Association 36: 97-104.

Ryan-Salter, T.P.; Black, A.D.; Andrews, M.; Moot, D.J. 2014. Identification and effectiveness of rhizobial strains the nodulate Lupinus polyphyllus. Proceedings of the New Zealand Grassland Association 76: 61-65.

Scott, D.; Charlton, J.F.L. 1982. Birdsfoot trefoil (Lotus corniculatus) as a potential dryland herbage legume in New Zealand. Proceedings of the New Zealand Grassland Association 44: 98-105. 
Scott, D.; Foote, A.G.; Baird, I.J. 1996. Perennial or Russell lupin. pp. 139-144. In: Practical herbage seedcrop management. Ed. Rowarth, J. Lincoln University Press, Lincoln University.

Scott, D. 1998. Sixteen years of caucasian clover under contrasting managements. Proceedings of the New Zealand Grassland Association 60: 115-118.

Scott, D. 2014. The rise to dominance over two decades of Lupinus polyphyllus among pasture mixtures in tussock grassland trials. Proceedings of the New Zealand Grassland Association 76: 47-52.

Smetham, M.L. 2003. Subterranean clover (Trifolium subterraneum): its history and current and future research in New Zealand. Legumes for dryland pastures. Grassland Research and Practice Series 11: 61-72.

Statistics New Zealand. 2016. Infoshare: Total annual sheep and beef cattle numbers for New Zealand. Accessed: 10/2/2016. URL: http://www.stats.govt. $\mathrm{nz} /$ infoshare/View Table.aspx?pxID=ff7 $1 \mathrm{~d} 03 \mathrm{e}-$ b5aa-498e-8d73-88d45350bfef. Last Updated: $15 / 12 / 2015$.

Stewart, A.; Kerr, G.; Lissaman, W.; Rowarth, J. 2014. Pasture and Forage Plants for New Zealand ( $4^{\text {th }}$ Ed.). Grassland Research and Practice Series 8. 139 pp.

Thomas, R.G.; Widdup, K.H.; Pankhurst, K.; Ryan, D. 1998. Reproductive potential of Caucasian clover at four locations within New Zealand. Proceedings of the New Zealand Grassland Association 60: 219-223.

Waghorn, G.C.; Douglas, G.B.; Neizen, J.H.; McNabb, W.C.; Foote, A.G. 1998. Forages with condensed tannins - their management and nutritive value for ruminants. Proceedings of the New Zealand Grassland Association 60: 89-98.

Wardle, P. 2016. War of the Lupins. New Zealand Geographic 137: 32-41.

Widdup, K.H.; Ford, J.L.; Cousins, G.R.; Woodfield, D.R.; Caradus, J.R.; Barrett, B.A. 2015. A comparison of New Zealand and overseas white clover cultivars under grazing in New Zealand. Proceedings of the New Zealand Grassland Association 77: 51-56.

Widdup, K.H.; Knight, T.L.; Hunt, L.M. 1996. Genetic variation for seed yield in Caucasian clover. Journal of New Zealand Grasslands Association 58: 189194.

Widdup, K.H.; Pennell, C. 2000. Suitability of new subterranean clovers in the Canterbury region. Proceedings of the New Zealand Grassland Association 62: 161-165.

Woodward, S.L.; Auldist, M.J.; Laboyrie, P.J.; Janson, E.B.L. 1999. Effect of Lotus corniculatus and condensed tannins on milk yield and milk composition of dairy cows. Proceedings of the New Zealand Society of Animal Production 59: 152-155. 
